\title{
How do borders influence migration? Insights from open and closed border regimes in the three Guianas
}

\author{
Simona Vezzoli@
}

\author{
Correspondence: s.vezzoli@hum. \\ leidenuniv.nl \\ Institute for History, Leiden \\ University, Doelensteeg 16, $2311 \mathrm{VL}$ \\ Leiden, The Netherlands
}

\begin{abstract}
The ways border regimes affect migration patterns remain ambiguous. Closed borders may constrain migration but also encourage migrants to pursue alternative migration channels and destinations. While open borders may be associated with higher migration, oftentimes they promote circulation and return. To clarify how different border regimes influence migration patterns, this article examines the impact of open and closed border regimes on migration outcomes in Guyana, Suriname and French Guiana in the 1950s-1980s period, when all three gained independence or non-sovereign status and colonial ties were strong. The article proposes a conceptual schematic model that can accommodate varied post-colonial political and border regime transitions and explains changes in the timing, destination and composition of migration. The analysis finds that, counterintuitively, closed borders can lead to high emigration while open borders can encourage people to stay. The proposed model also illustrates the relevance of three dimensions of time: the historical juncture, the sequence of change and the time span. In sum, rather than preventing migration, border regimes yield important effects that lead to migration diversification.
\end{abstract}

Keywords: Migration, Border regimes, Independence, Post-colonial ties, Historical juncture, Sequence of change, Time span, Pacing of change, Guianas, Guyana,

Suriname, French Guiana

\section{Introduction}

Research into the migration effects of opening and closing border regimes reveals ambiguous results. In some instances, opening borders, as during European Union (EU) enlargement phases, has resulted in short-term migration surges, but overall it appears to encourage greater circulation, including high levels of return, rather than growth of intra-EU migration (de Haas et al. 2019a). Studies examining the migration consequences of establishing a border regime that introduced migration restrictions between colonized and colonial states found that, in the short-term, it led to a migration surge, followed by a sudden migration reduction (Freeman 1987; Peach 1968). Yet, over the long-term, emigration rates tend to return to the pre-border norm (Flahaux and

(c) The Author(s). 2021 Open Access This article is licensed under a Creative Commons Attribution 4.0 International License, which permits use, sharing, adaptation, distribution and reproduction in any medium or format, as long as you give appropriate credit to the original author(s) and the source, provide a link to the Creative Commons licence, and indicate if changes were made. The images or other third party material in this article are included in the article's Creative Commons licence, unless indicated otherwise in a credit line to the material. If material is not included in the article's Creative Commons licence and your intended use is not permitted by statutory regulation or exceeds the permitted use, you will need to obtain permission directly from the copyright holder. To view a copy of this licence, visit http://creativecommons.org/licenses/by/4.0/. 
Vezzoli 2018). These ambiguities might arise from the lack of attention to distinct short- and long-term policy effects or they might be associated with the contradictory objectives within a full package of policy changes (de Haas et al. 2018). The mixed results might also be indicative of the limited effectiveness of migration policies and their unexpected effects on migration patterns (Czaika and de Haas 2013; de Haas 2011). In fact, while migration policies and border regimes may shape migration decisions and migration patterns, they alone cannot fully explain migration (see de Haas et al. 2019b). Border regime changes take place alongside other important political and economic transitions - such as entering the EU-bloc or gaining independence -, and these events have their own effects on migration. This article analyses the interaction of political and policy changes associated with the transition from colony to independence or incorporation with the aim to explain the influence of this process on migration patterns.

The transition to independence generally entails the curtailing of the freedom of movement through the establishment of a border regime, namely a set of restrictive migration policies. Although in most instances the former colonial state allowed some migration, residents in former colonies perceived that the border was closed and the former colonial state had slammed the door in their face. ${ }^{1}$ In addition to the border regime change, the political transition from colony to independence is very complex, entailing deep social and structural transformation, including ideological and psychological impacts, which might influence migration decisions. A study by van Amersfoort (2011) examined Suriname's independence and found that the political transition and border regimes changes interacted and shaped complex migration patterns. Suriname's independence from the Netherlands in 1975 triggered anxieties that generated an emigration rush to the Netherlands until 1980, when the border officially closed (van Amersfoort 2011). This study revealed that the nature (peaceful or tense) of former colonies' political transitions may have important migration consequences. It also disclosed that independence and border regime changes can take place at different times and the sequence and interplay between these two changes may have important and unexpected consequences for the nature, timing and composition of migration.

This article builds on van Amersfoort's work by analysing how the interaction between former colonies' political transitions and changes in border regimes affected migration in the three Guianas - Guyana, Suriname and French Guiana. Their similar histories, coupled with their differing post-colonial experiences, make for a 'natural experiment'. ${ }^{2}$ By examining the historical developments that led to independence or incorporation, this article presents how processes of decolonisation impacted living conditions and sets of opportunities available to people in former colonies, their decisions to migrate and ultimately led to major shifts in migration patterns.

The innovation presented by this article is twofold. First, through a narrative analysis of the three Guianas and their complex political and policy transitions, I propose a

\footnotetext{
${ }^{1}$ This paraphrases the statement of an interviewee in Guyana (GI2) and it reflects the emotional effect of the establishment of the border regime among many interviewees in Guyana and Suriname.

${ }^{2}$ In this article, the term 'post-colonial' is used to refer both to the period after independence and to the material and psychological impacts that affected former colonized people (Bosma et al. 2012), including migration decisions. While 'post-colonialism' entails power relations, of which the establishment of border regimes is a prime example, the aim of this article is not to explore power relations as pursued in 'postcolonial studies'. Rather, the term invites us to remain alert that these power relations impacted, and continue to impact, several aspects of life, including migration decisions.
} 
schematic conceptual model which can accommodate varied transition types and explain changes in the timing, destination and composition of migration. Second, the schematic conceptual model provides clarifications on how time shapes migration by proposing three distinct dimensions of time: the 'historical juncture' (Castles 2010), which for the analysed cases is the Cold War period; the sequence of change, namely the order and time between independence and border regime change; and the time span from the main events, distinguishing short- and long-term migration effects. Through this innovative analysis, this article reveals that, rather than preventing migration, border regimes associated with political status transitions yield important migration diversifications, which vary depending on whether border regimes were established before or after independence and whether the process of independence was peaceful or tense. Conversely, continuous open borders associated with non-sovereign status do not show emigration peaks but gradually changing emigration levels that reflect fluctuating socio-economic conditions, e.g. education, employment and incomes, in former colonies.

\section{The limitations of the current debate on the closure and opening of border regimes}

Existing evidence on border policy is often counterintuitive: border openings do not necessarily lead to large emigration, and closures do not necessarily end migration (de Haas et al. 2019b; Flahaux and Vezzoli 2018; Marshall 1987; Peach 1968). For example, in theory, EU enlargements and the opening intra-EU borders should have encouraged emigration from new to old member states. However, evidence points to more ambiguous patterns. The 1980s EU expansion did not lead to increased emigration from new member states Spain and Greece to older member states (de Haas et al. 2019a). When the Soviet bloc dissolved and its closed border regime ended, there were no massive flows from East to West but, rather, a short-term increase in emigration and a decrease in permanent emigration (Wallace 2002). In the late 1990s, when Central and Eastern European [CEE] countries experienced an economic downturn, emigration grew, regardless of border regimes in Western European countries (Engbersen et al. 2010). Curiously, when internal EU borders were removed for CEE accession countries, between 2004 and 2011, emigration rates did not increase uniformly from these new member states. Kureková (2011) suggests that low emigration rates from Hungary, Slovakia and Lithuania were associated with these countries' generous welfare provisions, while important economic hubs in CEE countries encouraged intra-regional migration from Poland, Romania and Ukraine to the Czech Republic, Hungary and former East Germany (Okólski and Salt 2014, in Engbersen et al. 2010). These findings reveal we cannot assume border openings increase migration; instead, we must account for contingent shifts, such as political and institutional changes.

Equally ambiguous is evidence on the effects of border closures. The main assumption is that establishing a restrictive border regime reduces migration. However, studies of West Indian migration to Britain after the British government introduced its 1962 Immigration Act, which essentially closed its border to its overseas citizens, show a more complex effect. In the short term, anticipation of the closed border regime led to a spike in emigration, referred to as 'beat the ban' migration (Marshall 1987; Peach 1968), followed by a sudden decrease. Policymakers at the time characterised the 1962 
Immigration Act as effective in reducing inflows in the following year, when, in fact, the Act caused a rapid increase before migration returned to its regular trend (Peach 1968). Thus, the short-term focus of many studies often misrepresents policy effects and ignores that many policy effects might only be visible in the long-term. Moreover, many studies tend to focus on volume with little or no attention to how border regimes might affect the timing and the destination of migration, and who is affected by border regime changes.

In an effort to account for these aspects, Flahaux and Vezzoli (2018) examined emigration intensity ${ }^{3}$ from Caribbean countries over the 1960-2000 period by disaggregating data according to their political status - i.e., independence or non-sovereignty and whether they had an open or closed border with the former colonial state. In closed-border countries, they found high emigration intensity that grew sharply as migration destinations diversified. On the contrary, countries that retained open borders saw emigration intensity decelerate. While this may be associated with higher living standards in non-sovereign countries (McElroy and Sanborn 2005), migration theories suggest that free mobility should encourage people to seek opportunities and better wages available to them in the former colonial state (e.g., metropolitan France, the Netherlands) or in other countries (e.g., EU member states). Yet, this is not visible. Moreover, non-sovereign countries with open borders for their overseas citizens experience much lower diversification of destinations both within the Caribbean and beyond. These findings suggest that (1) border regimes do not necessarily curb migration and, at best, deflect migration to other destinations; (2) border regimes clearly do not shape migration the way other political and socio-economic factors do; and (3) opening border regimes does not lead to higher emigration intensities. It remains unclear, however, how the political transition from colonial to post-colonial status and the change in border regime interact and ultimately influence migration decisions.

In sum, current research on the migration effects that result from border regime change has two main shortfalls: analyses largely fail to account for the complex set of events that accompany changes in border regime; and the concept of time is limited to observing migration patterns before and after the enactment of a border regime. This research moves beyond these limitations by introducing and accounting for three key dimensions of time:

(i) Historical juncture: This term, borrowed from Stephen Castles' work on examining migration through a social transformation perspective (Castles 2010), suggests that the analysis of deep social change must be embedded within a particular moment in history. In this way we can fully understand the impact of social change on society, on people's perceptions of social change and on migration decisions. For example, the specific historical moment of joining the EU can explain the migration effects of the removal of the intra-EU border regimes; and the geopolitical rivalries of the Cold War period can explain tense transitions to independence and important migration effects. Therefore, it is essential to embed the analysis of political status and border regime changes within a historical juncture in order to identify major forces at the national and international levels that could, ultimately, affect population's migration decisions.

${ }^{3}$ Emigration intensity is the percentage of migrants of all individuals born in a specific country. 
(ii) Sequence of change: The order of particular events can significantly shape social impact and, in this analysis, bear important migration consequences. For instance, closing the border regime after independence influenced migration patterns from Suriname to the Netherlands (van Amersfoort 2011); the reverse sequence led to distinct outcomes in Guyana, as shown later in this article. Through chronological ordering, characteristic sequences of events emerge (Abbott 2001, p. 177), which help us explain migrations in post-colonial settings.

(iii) Time span: When studying the effects of deep structural transformations, such as political transformations, economic restructuring and social transitions in post-colonial societies, it is paramount to adopt a long-time horizon. This enables observations of series of events, their diverse forms of interactions and varied effects on migration over time. The need to distinguish between the short- and long-term has already been acknowledged in the analysis of migration policy effects (Czaika and de Haas 2013; de Haas et al. 2019b). A long-time horizon also forces us to consider that changes take place at specific pacing or speed (Abbott 2001), so that gaining independence could be a swift or long process and a border regime could be quickly established or be the outcome of long negotiations. The pace of these changes can significantly affect migration.

After the methodology section, this article describes how political and policy transitions shaped migration in the three Guianas. These complex descriptive cases are simplified into a schematic model that reflects typical sequences (Abbott 2001) and that illuminate similar migration outcomes in other post-colonial settings. "The relevance of time" section presents an analysis of the three dimensions of time just described, and is followed by the "Conclusion".

\section{Methodology and data}

This article adopts a historical comparative perspective that relies on descriptive statistical analyses and in-depth qualitative analyses. Statistical analyses were based on migration data collected from historical sources (migration statistics and government labour reports) and from the DEMIG TOTAL and C2C databases. ${ }^{4}$ Additional data were collected from government reports, academic sources, newspaper articles. Qualitative analyses were based on the data sources just listed as well as 84 semi-structured interviews across the three Guianas conducted from 2013 to 2015 (see Additional file 1).

Although this research in its entirety focused on how short- and long-term transformations affected migration in the three Guianas, this article is limited to presenting shifts in migration patterns associated specifically with independence and border regimes. For the same reason, while the three Guianas have become immigration destinations, immigration is not analysed in this article. For the complete analysis of long-term migrations in the three Guianas, readers can refer to Vezzoli (2015).

\section{The three Guianas: a puzzle for the migration effects of border regimes and political changes}

Generally considered part of the Caribbean region (Gaztambide-Géigel 2004) despite being located on the South American continent (Fig. 1), Guyana, Suriname and French Guiana

${ }^{4}$ The migration flow databases compiled as part of the DEMIG project at the IMI University of Oxford are available at https://www.migrationinstitute.org/data/demig-data. 


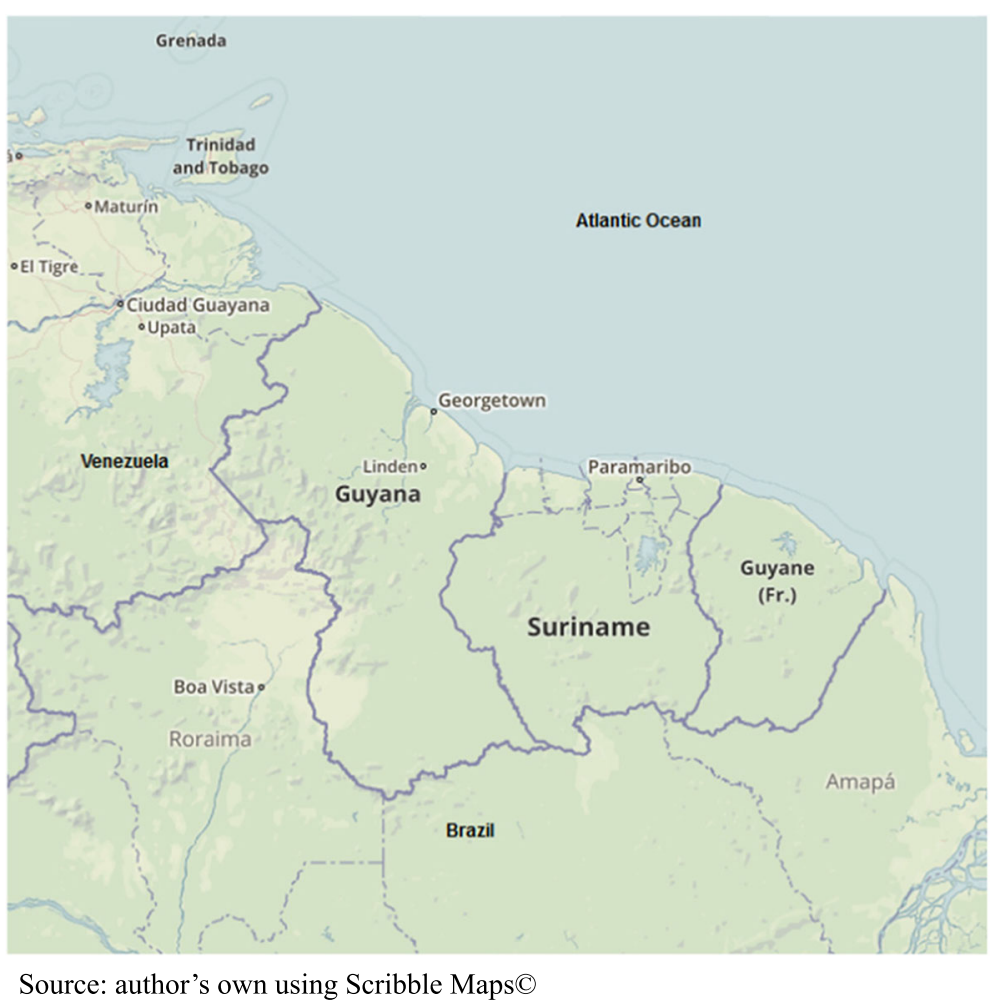

Fig. 1 Map of Guyana, Suriname and French Guiana

share a common history that includes colonialism, imposed European governance and institutions, and plantation and resource-extraction economies that relied on enslaved and contract labour and resulted in ethnically diverse populations. The three Guianas also have important differences: different European powers colonised them and each had a distinct political evolution. Guyana gained independence from Britain in 1966, but Guyanese lost their right to settle in Britain with the 1962 Immigration Act. Suriname obtained independence from the Netherlands in 1975, yet the Dutch government did not fully close its border with Suriname until 1980. French Guiana became incorporated into France as a French Overseas Department in 1946, making it part of the French state and giving residents freedom of movement within the French Republic that continues to the present day.

Their emigration patterns also differ (see Fig. 2), with Guyana and Suriname experiencing increasing emigration and French Guiana experiencing low emigration over the twentieth century (dark grey bars in Fig. 2). Why is emigration highest from the two countries that faced a closed border regime? Why does the absence of border restrictions not lead to more emigration from French Guiana? And why did migration from Guyana to Britain, its former colonial state, decrease and migration from Suriname to the Netherlands, its former colonial state, increase after independence (respective light grey bars in Fig. 2)? The three Guianas offer a 'natural experiment' to examine the underlying mechanisms associated with closed border regimes and to critically analyse the role that the concurrent political status transitions play in shaping the volumes, timing, direction and composition of migration. The following three sub-sections present a brief historical overview of the political and policy changes in each of the three Guianas and their specific shifts in migration patterns. 


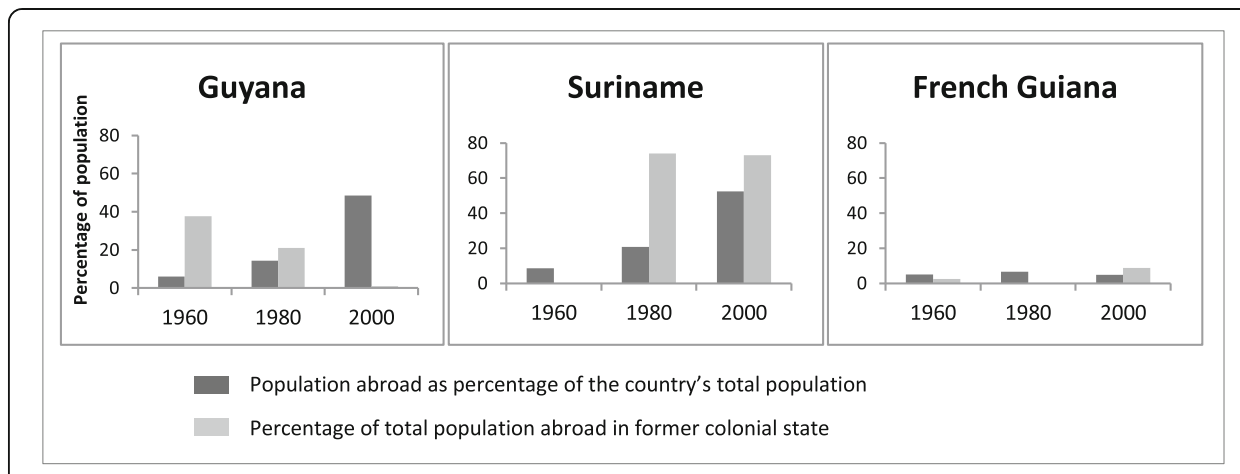

Source: World Bank Global Bilateral Migration Database and UN Population Estimates. ${ }^{5}$

Fig. 2 Percentage of population abroad and in former colonial state, Guyana, Suriname and French Guiana, $1960-2000^{5}$

\section{Guyana: citizenship without free mobility}

Throughout the 1950s and into the very early 1960s, emigration from British Guiana, Guyana's name before independence, was low and composed of citizens pursuing higher education or seeking employment in Britain and within the Caribbean region. A 75-year-old AfroGuyanese man who migrated to Britain in 1957 reflected about migration motives in this period, "To me it was education, and for most of them [his friends]. I would say all of them education or learning or advancement. Some of them went into the Arts, some went into acting, all sorts of different things." (GI25). In 1961, the British government, concerned with high levels of immigration from its vast current and former empire, particularly from South Asia and the West Indies, urged colonial administrators to control emigration. In British Guiana, the colonial administrators refused to enact any measures because of very low emigration numbers (Executive Council of British Guiana 1961). The British government took matters in its own hands by passing the 1962 Immigration Act, which essentially ended the right of citizens in the colonies to settle in Britain. The new border regime combined with the emergence of a Communist-inspired government as discussions of independence proceeded led to the sudden growth of emigration from British Guiana (Fig. 3, first peak). A 61-year-old AfroGuyanese man who migrated to Canada in 1969 stated,

"We were approaching independence and people were scared that, you know, that it would be another Cuba. So the whole thing was ... the middle class who were very often people of Portuguese, the Chinese descent. So, because, you know, I was in a Catholic school, lots of Portuguese were there too and so lots of friends would be leaving." (GI1)

The second emigration peak in 1966 (Fig. 3) corresponds with independence, which generated anxieties, particularly given tensions and violence among supporters of the AfroGuyanese ruling party and Indo-Guyanese opposition party. A 65-year-old Indo-

\footnotetext{
${ }^{5}$ World Bank's Global Bilateral Migration database 1960-2000, available at http://data.worldbank.org/datacatalog/global-bilateral-migration-database, accessed March 2013. The 2000 data was originally the Global Migrant Origin Database by the University of Sussex. United Nations, Department of Economic and Social Affairs, Population Division (2013). World Population Prospects: The 2012 Revision, DVD Edition, Total population (both sexes combined) by major area, region and country, annually for 1950-2010 (thousands), Estimates 1950-2010. These details apply to all graphs that use these two datasets throughout this study, unless otherwise specified.
} 


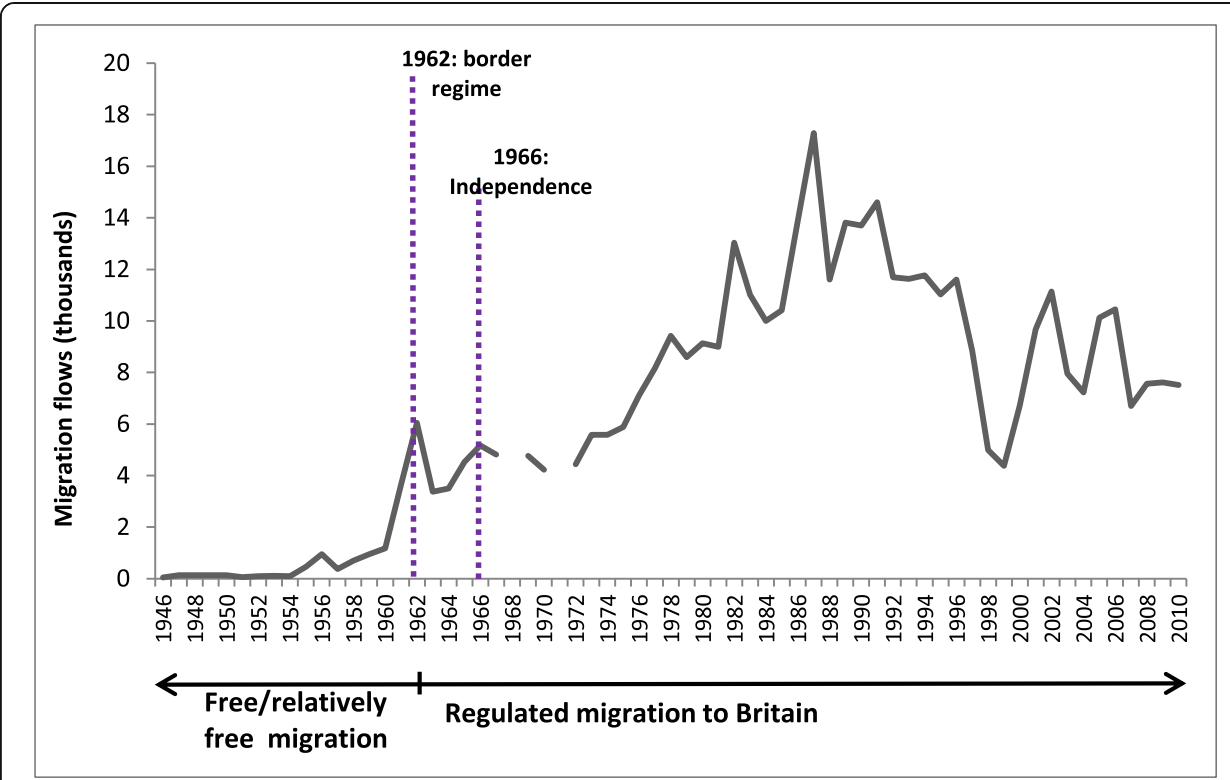

Sources: DEMIG TOTAL, DEMIG C2C, various annual British Guiana labour reports (between 1950 and 1967) and Peach 1968.

Fig. 3 Guyanese emigration, 1946-2010

Guyanese woman from rural Guyana who never left Guyana recalled, "in those days there were lots of ups and downs. You had racialism you know. This racialism with the Indians and the Negroes and all those things" (GI14). Nonetheless, the independence migration peak is smaller than the one the border regime triggered. Two factors account for this difference. First, despite political tensions, Guyana had a popular independence movement (Laing 1979), and socio-economic developments pointed to a positive outlook postindependence (Sanger 1966). ${ }^{6}$ An Afro-Guyanese man who was 9 years old at independence stated, "Actually, independence was not a call for fleeing or riot, I should say. It was, it was a festive thing. At the time that I remember. It was very festive and everyone was happy to hear we are not flying the Union Jack anymore here, we are getting what is called the Golden Arrowhead." (GI17). Second, closed borders with Britain, the most likely destination, reduced migration opportunities and led to some, albeit limited, redirected migration. While migration flows to Britain scarcely changed in the 1963-1968 period, emigration to the British West Indies and North America continued to grow (Fig. 4). It would take a few more years before the United States became the dominant destination, but Guyanese began to redirect their attention from Britain's restrictive policies to North America, where policies had become less restrictive towards non-European migrants. ${ }^{8} \mathrm{~A}$ 60-year-old Indo-Guyanese man who eventually migrated to the US in 1981 exclaimed, "If I could I would have gone to the UK, I most likely would have gone, but that door was shut in my face!" (GI2).

\footnotetext{
${ }^{6}$ The welcoming attitude towards independence was shared among the eight interviewees who lived through the transition to independence (see Additional file 1).

${ }^{7}$ Golden Arrowhead refers to the pattern on the Guyanese flag.

${ }^{8}$ Figure 4 also suggests that the small labour recruitment programmes introduced by Canada and the US provided the Guyanese a first entry in North America (Vezzoli 2015).
} 


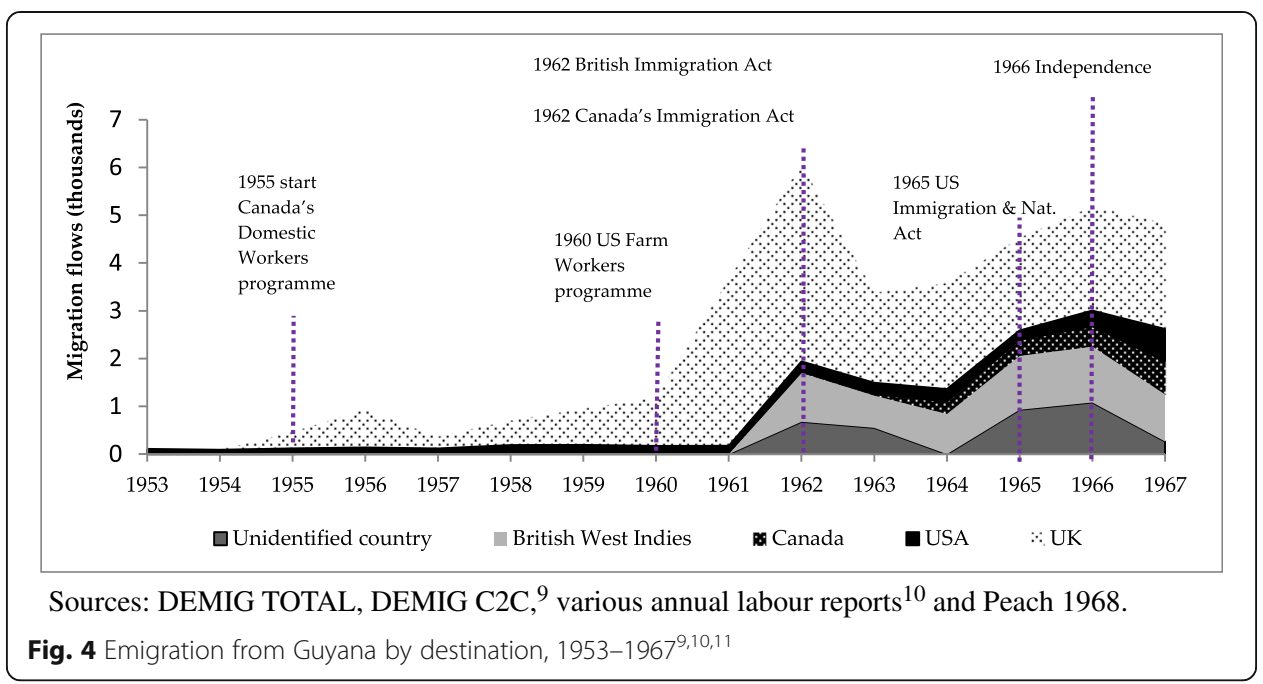

Independence also implied a change in who migrated: particularly, middle-class IndoGuyanese targeted by the ruling Afro-Guyanese party left in greater numbers. A 79year-old Indo-Guyanese woman who re-emigrated with her husband to Britain in 1972 stated, "You know, you had hmmm, the jobs were not given to the Indians. He [her husband] heard of this nationalization and hmmm, you know the sugar industry was being nationalized and within hours he made up his mind and he said no, no, no we are not staying here. Overnight, we left the next day. But of course, we were British citizens and so we had an opportunity of going. [ ...] He said, no, he don't want to stay any longer because he had to ... you know...he was called upon to give people jobs or employ people who didn't have any qualifications at all. And so he thought that it was very, very unfair you know." (GI11). Despite worsening living conditions, only a small segment of the population had the means and connections to emigrate right after independence. This evidence suggests that the new border regime and independence might have had shortterm effects if the political and socio-economic conditions had not become more precarious over the 1970s-1980s, leading to numerous emigration peaks after the 1960s and the overall growth of emigration, which peaked in the late 1980s (Fig. 3). However, the 1962-1966 period ignited the growth of strong Guyanese communities abroad, while the early closure of the British border to its former colonies diminished the

\footnotetext{
${ }^{9}$ DEMIG (2015) DEMIG TOTAL, version 1.5. Oxford: International Migration Institute, University of Oxford; DEMIG (2015) DEMIG C2C, version 1.2, Full Edition. Oxford: International Migration Institute, University of Oxford. Both databases are available at http://www.imi.ox.ac.uk/data).

${ }^{10}$ British Guiana (1952), Annual Report of the Commissioner of Labour for the year 1950, Georgetown, Demerara, British Guiana; British Guiana, Annual Report of the Department of Labour about 1956 (approximate title and year, because report missed the title page); International Labour Office, Expanded Programme of Technical Assistance (1957) Report to the Government of British Guiana on Employment, Unemployment and Underemployment in the Colony in 1956, Geneva; British Guiana, Annual Report of the Labour Division of the Ministry of Labour and Social Security for the year 1964; Guyana (1967), Annual Report of the Department of Labour of the Ministry of Labour and Social Security, for the year 1965, Georgetown; and Guyana (1968), Annual Report of the Ministry of Labour and Social Security for the year 1967, Georgetown. All reports retrieved from the Walter Rodney Archives, Georgetown, Guyana.

${ }^{11}$ Due to incomplete data, emigration figures may be underestimated. For instance, the peak in 1956 does not represent a real increase in emigration but is due to a more complete data set for 1956. The same is true for data starting in 1962. This weakness in the data does not undermine the effects of border closure, as total outflows data support the trend (DEMIG TOTAL).
} 
potential effect of post-colonial ties and helped to establish North America as a major destination.

\section{Suriname: non-citizens with mobility privileges}

From 1964 to 1971, migration out of Suriname gained strength and changed in character (Vezzoli 2015). Pre-1964 emigration was associated with higher education and a search for adventure (Gowricharn 2004). In the 1960s, young women were recruited to train and work as nurses in the Netherlands. This period also saw deteriorating socio-economic conditions, technological innovation, high unemployment rates (Dew 1978) and social unrest (Menke 1998) in Suriname, which led to increasing emigration to the Netherlands. By the early 1970s, migration was an investment in the future. A 60-year-old Hindustani man who emigrated in 1972 indicated that, in this period, it was common to hear, "I am going to give my children more opportunities to study in Holland" (SI18).

With independence, migration peaked: 40,000 Surinamese left in 1975, four times the 1971 figure (Fig. 5). Unlike in Guyana, where the overall population supported independence, in Suriname independence was the elite's movement and it did not reflect a popular desire for self-representation (Chin and Buddingh' 1987; Moore 2001). Opposition to independence grew over time within the political sphere (Dew 1978) and among the Creole population, the main ethnic group that had initially most strongly supported decolonisation. Feelings of uncertainty ramped up as political disagreements intensified and became entrenched with ethnic politics. A 54-year-old Hindustani man who was 15 years old at independence remembers, "everybody was moving so we moved also. [ ...] I think the thought was that Suriname would become worse after independence year." (SI22).

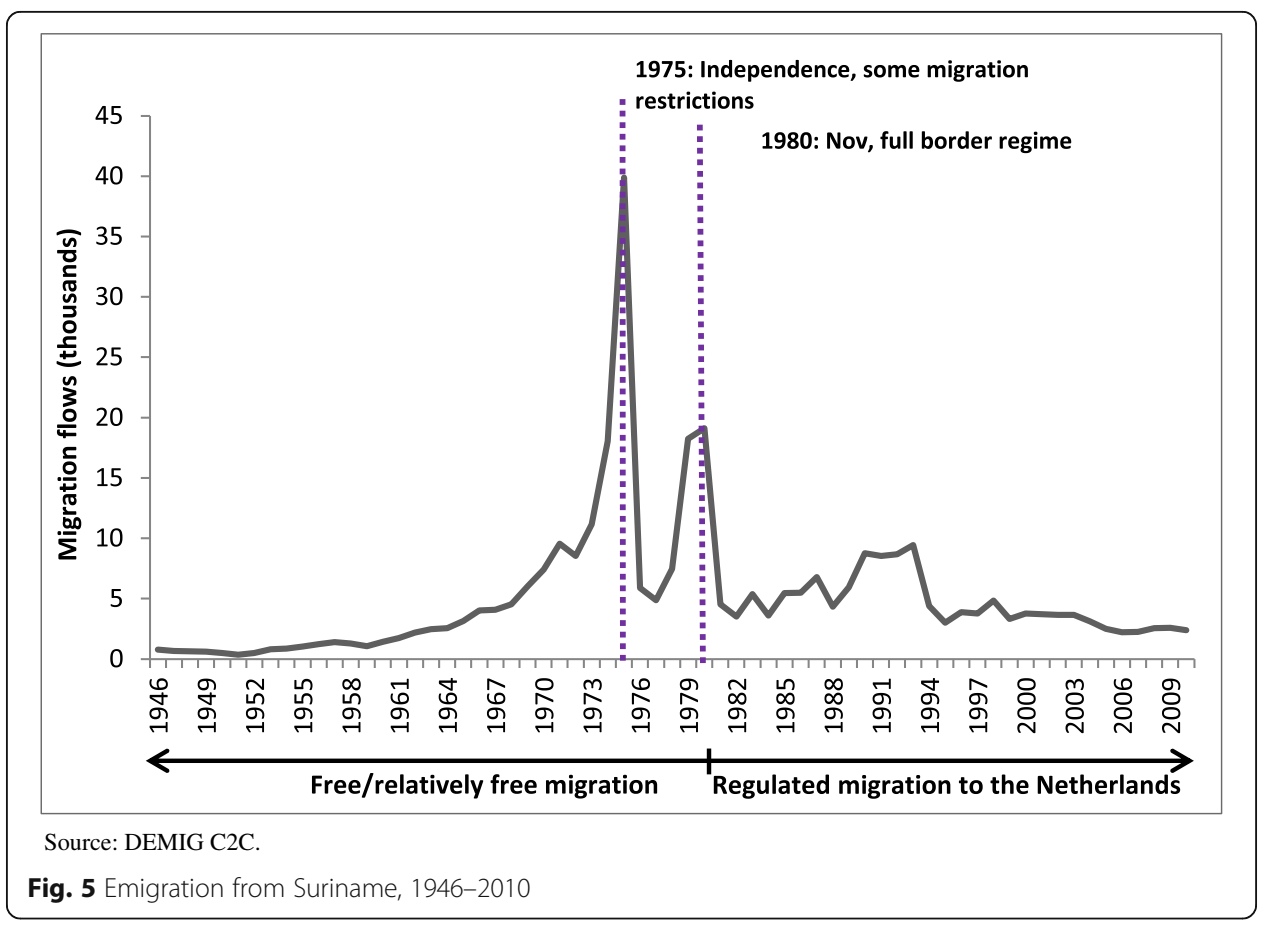


Contributing to growing anxieties was news of unstable conditions in neighbouring independent Guyana, where the Afro-Guyanese group controlled the government after independence. News about Guyana's chaotic situation reached Suriname through hearsay and from Guyanese who migrated to Suriname at this time. Among the Javanese population of Suriname, Indonesia's violent independence process resounded, raising fears that the same would happen in Suriname. A strong fear among the Hindustani population was the loss of hard-earned assets and "being thrown back into poverty" (SI19), ${ }^{12}$ while the Javanese population was encouraged to emigrate during independence negotiations by its own ethnic party. Dutch citizenship, which could be secured by being on Dutch territory on independence day in November 1975, provided a safe solution to this fears and led to the rush to 'beat the ban' so clearly visible in the data (Fig. 5). The Netherlands became a safe haven for many Surinamese, as stated by a 46-year-old woman who remembered discussions in her family, "well, let me go to Holland because in that case I am at least sure about the system and things like that." (SI9).

Figure 5 does not show the major shift in migration composition within this peak, which made up $10 \%$ of Suriname's population and included many who had never considered emigrating (e.g., less educated, rural and older individuals). A support network emerged through which even poor families received assistance from friends, relatives and even community members to leave in time to acquire Dutch citizenship. ${ }^{13}$

Surinamese politicians negotiated the independence agreement so that Surinamese citizens would retain mobility rights to the Netherlands and even Dutch citizenship rights for a five-year period. Thus, until November 1980, Surinamese enjoyed the right 'to obtain a three-month residence permit in the Netherlands and, on conditions that he/she be selfsupporting, could obtain Dutch citizenship' (Chin and Buddingh' 1987); they also enjoyed visa-free travel. These policies imposed relatively low restrictions that enabled strong Surinamese communities to form. In turn, these communities ensured readily available financial and human capital to support further migration. The gradual process of family migration is described by a 62-year-old Amerindian woman, "When I was there in the first 5 years of my study, I came back here for vacation but also to get my sister to come over and live there. And that's how they all went, one by one." (SI20). By 1980, migration was an attainable possibility for large portions of Surinamese society.

Starting in November 1980, Surinamese citizens needed a travel visa and, if they wanted to stay longer, a work permit that was issued upon demonstrating adequate housing. This context explains the 1979-1980 emigration peak, linked to border closure. The 1980 emigration peak was about half the 1975 peak, despite the fact that, in addition to border closure, Suriname experienced a coup d'état in February 1980. The coup generated some uncertainty, but it did not lead to the expected emigration increase. $^{14}$ This seems to support the notion that open borders with the Netherlands

\footnotetext{
${ }^{12}$ Two interviewees described in great detail how their families felt threatened and feared the loss of their assets in anticipation of independence. In both cases, the families sold all assets and emigrated to the Netherlands.

${ }^{13} \mathrm{~A}$ detailed description of this process emerged from one interviewee who personally assisted a poor family in meeting the financial requirements and establishing contacts to migrate to the Netherlands.

${ }^{14}$ Several interviewees discussed their perception of the 1980 coup and how it was not an important trigger for emigration. It was only later, in the early 1990s, when the authoritarian government strengthened its hold, that more people chose to leave.
} 
encouraged various population segments to migrate in anticipation of the future border closure and eventually led to what could be described as a 'saturation' of emigration in the population. The sequencing of independence before border closure, coupled with the 5-year gap between the two events, engendered a particularly strong concentration of Surinamese migrants in the Netherlands. This display of post-colonial ties is certainly also due to cultural, language and institutional connections as this 75-year-old woman emphatically stated, "Listen, when I was born, I was born Dutch" (SI21). Yet, Surinamese seeking to emigrate before the 1980 border closure did not need to explore alternative destinations, unlike the Guyanese redirecting to the US. In fact, Surinamese perceived US migration policies to be very strict and not worth the risk. Hence, when border regime closure follows independence, strong migrant communities in the former colonial state magnify post-colonial effects, reduce the effectiveness of border closures and decrease the willingness of potential migrants to pursue alternative destinations.

\section{French Guiana: freely mobile citizens}

The former colony of French Guiana, also called Guyane, became part of France in 1946 as a French Overseas Department (DOM, Département d'Outre-Mer). ${ }^{15}$ Over the years, French Guiana's administrative functions have changed, with greater autonomy in specific socio-economic areas. Yet certain functions and public funding still depend on France's central government. In terms of mobility rights, the 1946 political transition did not reduce but rather consolidated French citizenship and, with that, the right of French Guianese to travel, reside and work in any part of the French territory as full-fledged French citizens. In other words, any movement from French Guiana to other parts of France is considered internal migration.

In contrast with Guyana and Suriname's migration trends, French Guiana's emigration (Fig. 6) has grown gradually, albeit with some fluctuations. Citizens have not experienced moments of heightened uncertainty around major political or mobility shifts. Instead they have experienced stability. Whenever social tensions arose, the central government intervened with plans to expand services and create more public-sector jobs. For example, the 1980s decentralisation process, which entailed financial contributions, institutional projects and further expansion of public employment, correlates with a visible reduction in emigration between 1982 and 1990 (Vezzoli 2015). In particular, the expansion of public employment has been central in the retention of people. A 51-year-old Indo-Guianese non-migrant man working in the public sector in Cayenne indicated that emigration was risky as it meant losing a public sector job that would be hard to get back (FGI1). Moreover, migration was often geared towards improving skills, preparing for and passing the civil servant exam, and obtaining public work.

Data from the 1999 census confirms a return to the trend of very gradual emigration increases. However, because French Guiana has been stable and living conditions have been and continue to be relatively high, emigration levels have remained low. A 43year-old Creole man who returned from long stays in Paris and later in New Caledonia

\footnotetext{
${ }^{15}$ The other DOMs created in 1946 are Guadeloupe and Martinique (the French Antilles) and Réunion in the Indian Ocean.
} 


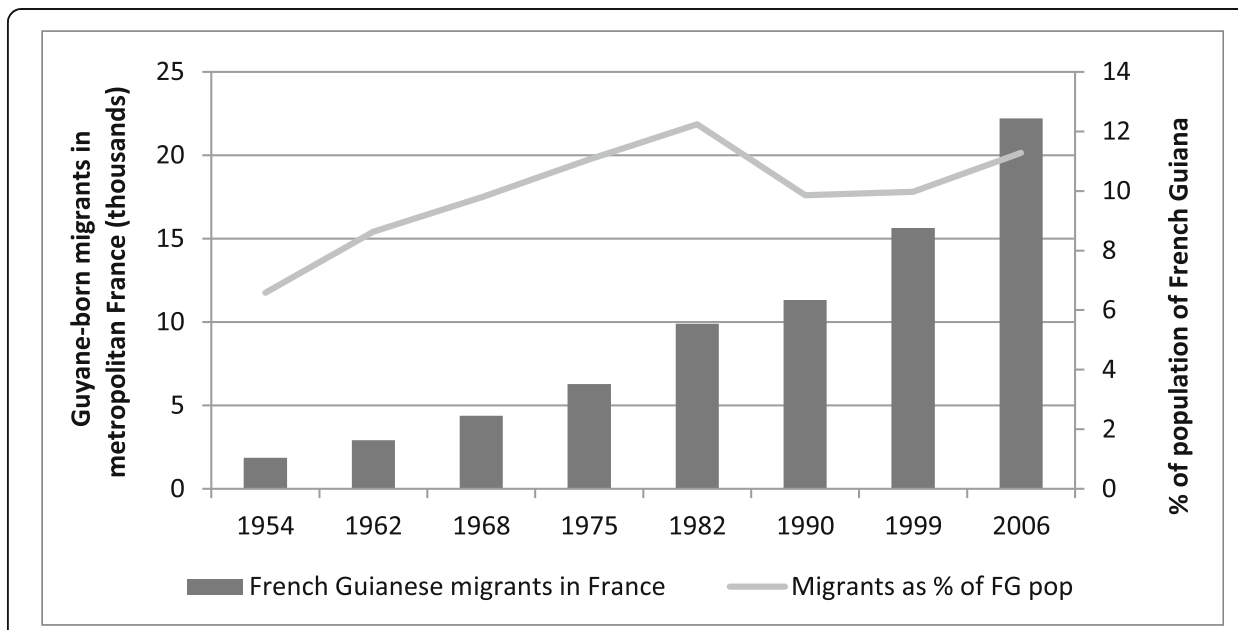

Source: Censuses of metropolitan France, Marie et Rallu 2004, INSEE data. ${ }^{16}$

Fig. 6 French Guiana-born population in metropolitan France, 1954-200619 (Marie et Rallu 2004) $^{16}$

indicated that not many of his friends left, and of those who left, some have returned and are now settled family men in Guyane (FGI13). Yet, in the early twenty-first century statistics show a gradual increase in emigration among young Guianese seeking advanced education and specialised employment not available in Guyana (Temporal et al. 2011). Thus, migration is shaped by people's educational, employment and professional aspirations rather than by border-regime requirements. Moreover, we find various forms of spontaneous movement ranging from short-term visits to long-term migration and return (Table 1).

A key observation is that, overall, Guianese have been exempt from the 'anxieties' and barriers associated with visa eligibility, complex procedures, long waiting periods and visa durations, topics that were highly familiar to Surinamese and Guyanese. A 28year-old Creole man wishing to migrate to the US, exclaimed surprised, once he realized that he would need a visa, "You say that I have to go through the same punishment (galère) that Brazilians and Georgetownians ${ }^{17}$ have to go through here!" (FGI16). For many Guianese, migration should neither be difficult or risky: a 30-year-old Creole woman explained that state should provide financial support to those who want to migrate and also support their integration when they are ready to return (FGI11), while another Creole woman, 43-year-old, who visited metropolitan France for short periods, indicated that she would migrate to metropolitan France only if she was provided an apartment and a car (FGI4). This reveals an extraordinary perception of what the state should do to facilitate migration. It also shows that migration is a 'low-stress' endeavor: it is not rushed, not 'caught on the fly' as a sudden opportunity, not a big event worthy of daily discussions or a celebration, as it might be in Guyana. In French Guiana, emigration results from a personal plan that is embarked upon when the person is ready. At a macro level, this results in steady migration that is not concentrated in peaks.

It must be noted that, even without migration barriers, some Guianese do not have the ability to emigrate due to low levels of human, social and financial capital.

\footnotetext{
${ }^{16}$ Data available at uneven time intervals. Data available at http://www.insee.fr/fr/insee_regions/guyane/ themes/ter/ter2010/ter2010_03_gy.pdf, Accessed February 2014.

${ }^{17}$ People from Georgetown, a term used to describe immigrants from Guyana.
} 
Table 1 Migration history of French Guiana-born individuals, based on residence in French Guiana or metropolitan France (\%)

\begin{tabular}{clllll}
\hline $\begin{array}{l}\text { Migration } \\
\text { history }\end{array}$ & $\begin{array}{l}\text { Natives } \\
\text { who never } \\
\text { left }\end{array}$ & $\begin{array}{l}\text { Natives who left for short } \\
\text { stay abroad (less than 6 } \\
\text { months) }\end{array}$ & $\begin{array}{l}\text { Returnees } \\
\text { (long-term } \\
\text { migration) }\end{array}$ & $\begin{array}{l}\text { Natives still abroad } \\
\text { (long-term } \\
\text { migration) }\end{array}$ & $\begin{array}{l}\text { Total } \\
\text { natives }\end{array}$ \\
\hline $\begin{array}{c}\text { Age group } \\
\text { Aged }\end{array}$ & 17.3 & 40.0 & & & \\
$\begin{array}{l}\text { 18-34 } \\
\text { Aged }\end{array}$ & 16.4 & 42.1 & 12.4 & 30.3 & 100 \\
$18-79$ & & & 15.4 & 26.2 & 100 \\
\hline
\end{tabular}

Source: Merged data from two tables in Temporal et al. 2011, original sources are Ined-Insee, MFV 2009-2010 and 2007 census data

Interviewees indicated that it is essential to have contacts to rely on while searching for a job and an apartment in metropolitan France, but having contacts did not always mean the successful settlement there: in fact, interviewees suggested that friends and family support only for short periods of time, which might not be sufficient to find a job and housing. These difficulties are particularly true for people from French Guiana's forested interior, where gathering the resources and contacts to migrate, not only overseas but also internally, may be very difficult (Osburg 2020).

When we consider migration destinations, we observe that emigration has been mainly directed towards metropolitan France $^{18}$ and a number of destinations within the French sphere, such as the French Antilles, Réunion, Mayotte, New Caledonia and, recently, Quebec in Canada. Linguistic similarities matter when choosing a destination like Quebec. But what is striking is Guianese choose other islands that might not offer much in terms of employment but do share French institutions, regulations and services, including the possibility of a mutation, namely a job transfer within the public sector. While these destinations are low-risk, they provide the chance to experience new realities. Some destinations also allow Guianese to reconnect with their parents' birthplace, such as the French Antilles.

Overall, the open border between French Guiana and all of France's territories has led to gradually increasing migration that reveals two coexisting positions. First, emigration is unappealing because people perceive French Guiana overall positively in comparison to neighboring Suriname, and Guianese tend to have mixed feelings about life in metropolitan France. If on one hand, metropolitan France is a place of excitement and opportunities, it is also expensive, there is discrimination, and "it is cold and people get angry there!" (FGI1). Second, unemployment, limited professional outlets, insufficient social services and feelings of disenfranchisement drive some people to seek better opportunities in metropolitan France. Indeed, we observe both trends taking place, with a growing number of young people leaving for educational and professional reasons, although most chose not to migrate (Marie et al. 2012; Temporal et al. 2011). In stark contrast to Suriname and especially Guyana, a strong feeling of freedom and spontaneity of movement pervades Guyane, a feeling captured beautifully in this quote by a 25-year-old Creole man, "You see those flowers on the palm tree? They fall down

\footnotetext{
${ }^{18}$ In 1990, about $68 \%$ of Guianese returnees had been in metropolitan France, a low percentage compared to 88-91\% for the French Antilleans (Guengant 1993).
} 
and then the wind comes and it blows them away. I am like that. I am here now but I don't know about tomorrow." (FGI15).

\section{A schematic conceptual model to explain migration effects}

The narratives presented above illustrate how changes in political shifts, including power relations with the former colonial states and other global players, tensions between ethnic groups, political and economic instability and state interventions, shape migration outcomes. To disentangle the complex dynamics within these narratives, this section presents a schematic model which reflects the three sequences observed in the Guianas and can teach us about the relationship between changing border regimes, shifts in political status and migration patterns: (1) border closure before independence, (2) border closure after independence and (3) non-sovereignty and continuous open borders.

\section{Border closure before independence}

In Guyana, as in most British Caribbean countries, the establishment of a border regime anticipated independence, resulting in a two-peak emigration pattern (Fig. 7). The closure of the border affected primarily those who already intended to migrate, although political instability and discussions of upcoming independence in Guyana encouraged others to emigrate strategically before opportunities to do so ended. Alternative migration destinations, both within and outside the British sphere, were already visible before border closure.

The border closure impacted the volume, channel and destination of migration trajectories from Guyana. By independence, migration patterns were already diversified. Under these conditions, post-colonial ties weakened rapidly. With independence, a second, sudden rush of anticipated migration ensued. This time, more migrants chose

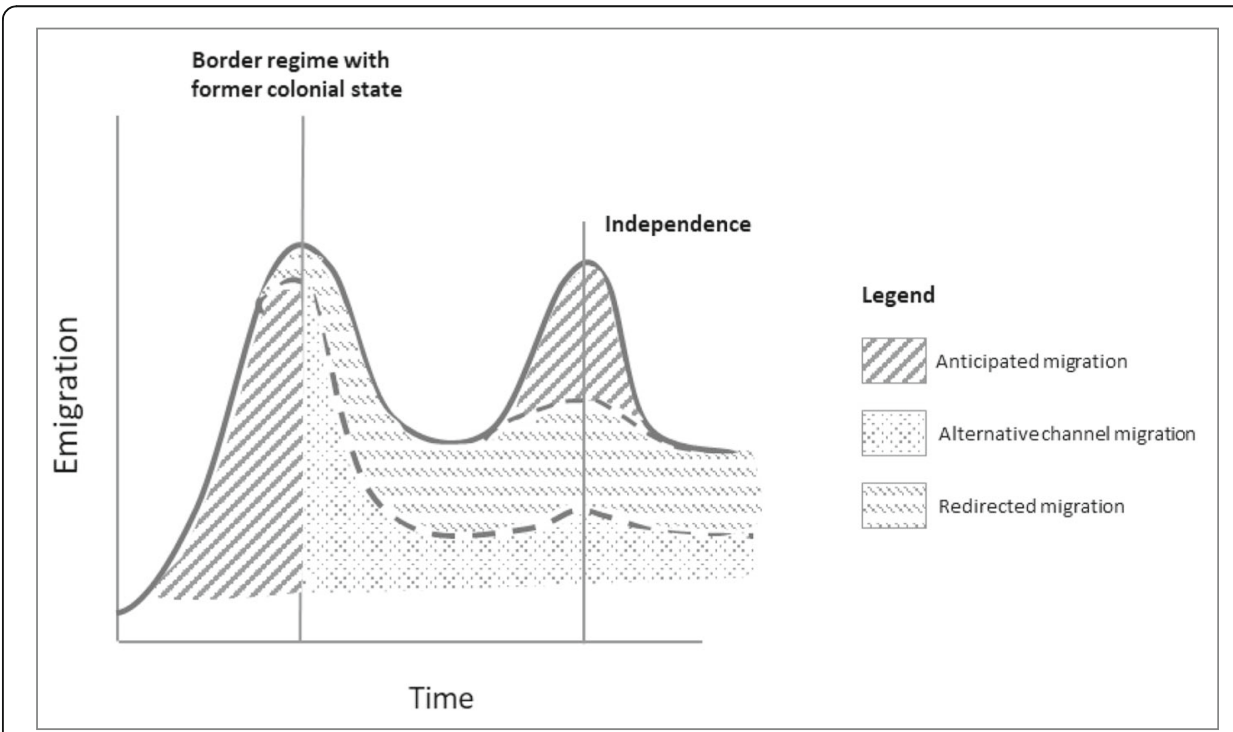

Source: Vezzoli, 2015.

Fig. 7 Schematic representation of how establishment of a border regime followed by independence affects international migration 
alternative destinations (primarily North American and the British Caribbean) and pursued new migration channels (family reunification and increasingly unauthorized channels), rather than the labour and study channels of the pre-border regime period. In Guyana, where independence was perceived overall positively but negatively among some segments of the population, the peak associated with independence was lower than the border-induced peak, potentially suggesting that, in the short-term, the border closure prevented higher emigration. However, the size of the independence-triggered peak may vary depending on the newly independent country's stability and outlook, the strength of post-colonial connections and the migration policies of alternative destinations.

This sequence of events accompanies a shift in migrant composition: the elite and middle classes were overrepresented in the first peak because of the combination of the border regime change and fears of Communism. This group had assets to protect, and the political connections and the resources to migrate, which the lower classes did not have. Individuals fearful of independence-related changes, even those with few resources, dominated the second peak. The significant political and ethnic divisions led to growing numbers of people fearing worsening conditions in Guyana, but limited migration opportunities resulted in the growth of migration to neighbouring countries and through irregular channels, leading to the greater diversification of migrant characteristics and migration destinations.

\section{Border closure after independence}

When independence anticipated border closure we observed two lumpy peaks (Fig. 8). Because the uncertainties tied to independence were great but the Dutch government insisted on giving independence to Suriname, a large portion of the population emigrated before independence. Migration was a pre-emptive measure to ensure the retention of settlement and citizenship rights in the Netherlands. As in Guyana, the

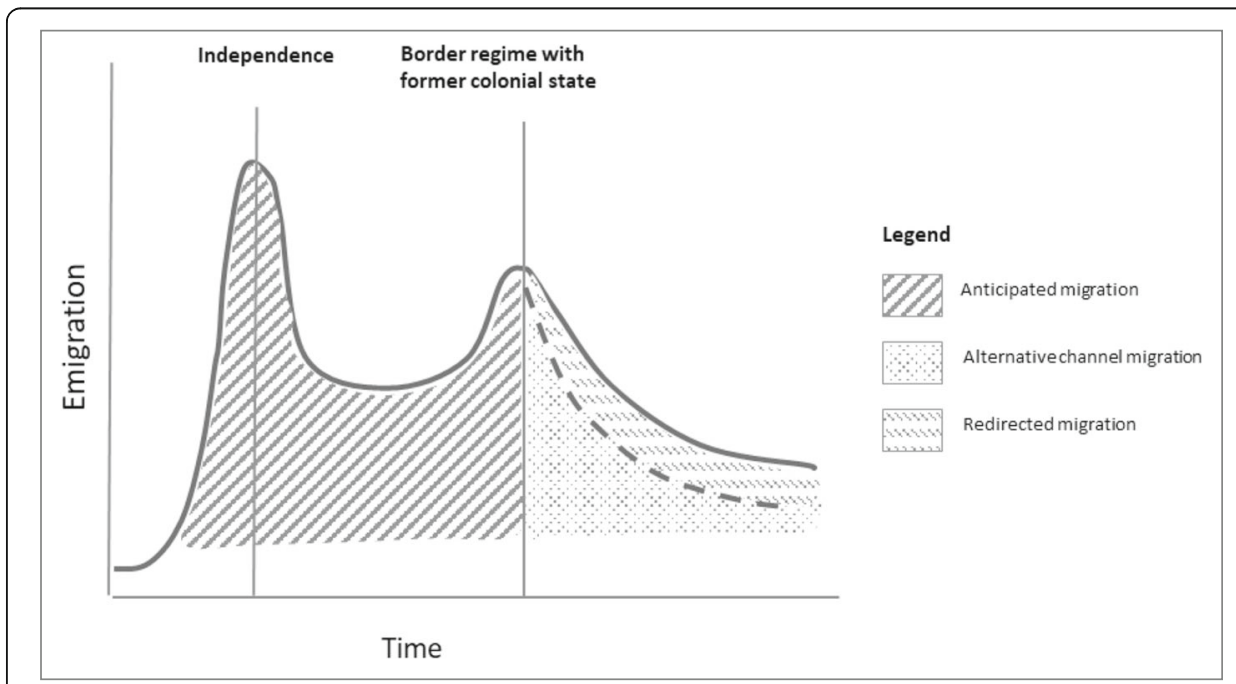

Source: Vezzoli, 2015.

Fig. 8 Schematic representation of how independence before the establishment of border regime affects international migration 
anxieties of a political transition were combined with tensions resulting from significant ethnic divisions, making migration a strong preference for certain ethnic groups. Unlike in Guyana, however, many people could take advantage of lower migration barriers to the former colonial state and emigrate pre-emptively. This enabled many families, even those with few financial resources, to send at least one individual to the Netherlands as a risk-diversification strategy.

After independence people continued to migrate, but many displayed a 'wait and see' attitude, allowing the ruling powers in Suriname to show leadership and visible signs of stability and economic growth. Regardless of the outcomes, emigration generally increases before border closure. So, even in this case, migration increased ahead of the impending restrictions. Nonetheless, the second emigration peak's volume was lower than the first one for several reasons: first, the uncertainties tied to independence were much greater than those triggered by the border regime implementation and second, many people who intended to migrate had already done so since independence. Finally, after the border regime was fully established, potential emigrants had to identify viable migration channels or alternative destinations. Contrary to Guyana (Fig. 7), in this case large migrant networks in the former colonial state had been established since independence, making it less likely that potential emigrants would explore alternative migration destinations. Hence, this sequence of events generally leads to migrants forming strong communities in the former colonial state, magnifying post-colonial effects.

\section{Non-sovereignty and continuous open borders}

The transition to non-sovereignty while maintaining open borders with the metropolitan state generated smaller levels of emigration (Fig. 9) than with independence and border closure (Figs. 7 and 8). Moreover, different dynamics shaped this small change in volume. While countries facing uncertainties around independence and border

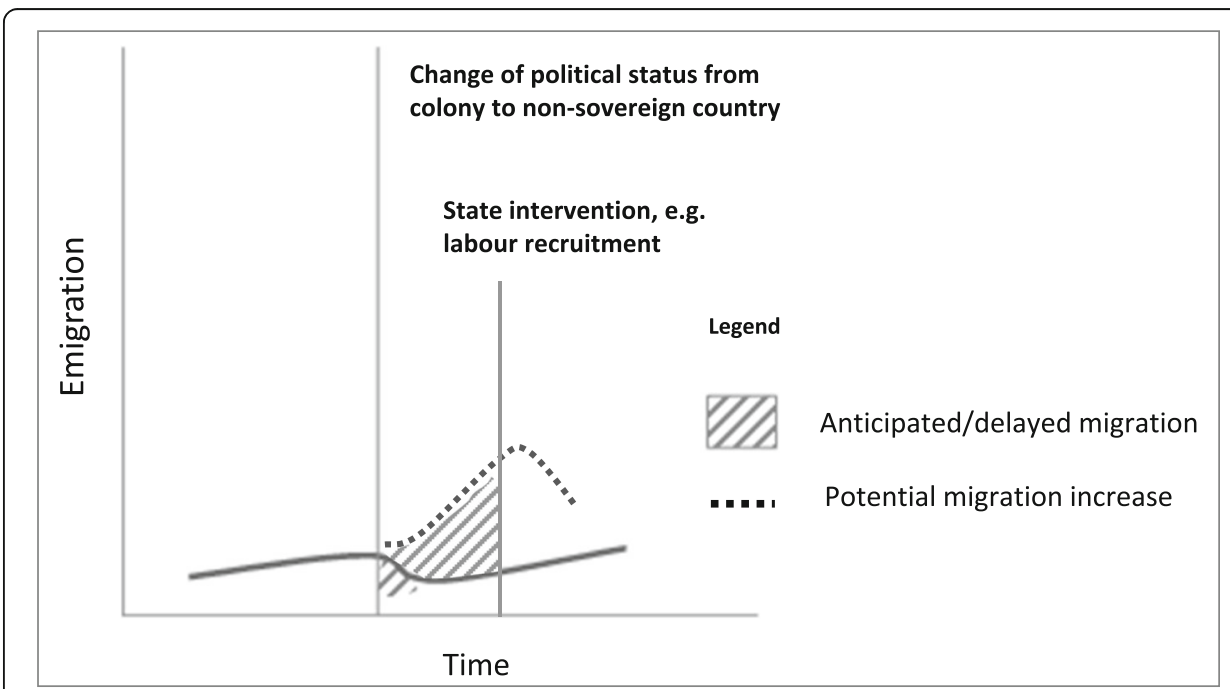

Source: Adaptation of Vezzoli 2015.

Fig. 9 How political status change from colony to non-sovereignty possibly affects internal and international migration 
closure experienced strategic migration in anticipation of key events, in French Guiana the change in migration occurred after the transition to non-sovereignty. Moreover, it resulted in lowered emigration because people expected their quality of living to improve. Under these conditions, emigration would generally lower, at least in the short term.

With open borders and non-sovereignty, ease of movement may lead to spontaneous migration with no migration peaks (Fig. 9). Emigration tends to react to specific events, such as socio-economic reforms, large development projects or the opening of a university. Most people migrate to the metropolitan state, with little emigration to alternative destinations, ${ }^{19}$ and we observe high levels of circulation and return migration. Open borders also lead to a more diverse migrant population, including greater numbers of lower educated and rural migrants (Grosfoguel 1996).

Deviations from these migration effects are possible. First, state interventions may create migration peaks. A notable example is labour recruitment programmes, such as France's 1960s program for French Antilleans to work in various industries (see dotted line in Fig. 9). Such initiatives result in spontaneous migration in later years. Second, because non-sovereign countries may reach high levels of political and economic stability, they may experience high immigration, particularly from neighbouring independent countries with lower standards of living and greater instability (McElroy and Sanborn 2005; Mitchell and McElroy 2011). Third, some non-sovereign countries have experienced closed border regimes, namely the British West Indies (Clegg 2005). Their migration patterns generally reveal that people seek to overcome the metropolitan state's restrictions by seeking alternative destinations (Flahaux and Vezzoli 2018).

Overall, emigration from non-sovereign, open-border countries is spontaneous and involves most segments of society, although the poorest may be excluded due to lack of capabilities. Also, it may entail various forms of mobility with high levels of circulation and return. The latter reflects the fact that citizens know borders will remain open, leading them to engage in migration only if and when needs arise.

\section{The relevance of time}

This section analyses how time influenced migration patterns in the three case studies, with the specific aim of observing the analytical contributions of the historical juncture, the sequence of time, and the time span.

\section{Historical juncture}

Understanding the historical juncture means being aware of and accounting for the influence and intersection of global and national factors on social processes at a specific moment in time. Global factors include independence movements and the role of communism, for example, while national factors centre on economic conditions, ethnic or class divisions and fear of political change. In essence, the dynamics of independence during the Cold War were specific to that historical juncture and would differ from processes of independence gained in the current neoliberal framework. The set of factors that affect governments, institutions and people's livelihoods are peculiar to a specific time (Abbott 2001). It is this specific set of factors that shape migration volumes,

\footnotetext{
${ }^{19}$ Nevertheless, we may observe people shifting preference to alternative destinations, in which case migrants may need to change migration channels.
} 
motives, destination selection and migrants' propensity to return to a newly independent country.

Through this lens, it is relevant that Guyana's independence struggle took place during intense Cold War activities. The US government promoted fears of Communism in Guyana, which affected Guyana's politics and encouraged some segments of society, namely the entrepreneurial class, to rapidly emigrate. Similarly, the Dutch government's rush to grant Suriname independence must be understood within its decolonisation strategy, fears of immigration and economic pressures. That eagerness led to Suriname's hurried and anxiety-ridden process with a high emigration rate as an outcome. In ethnically diverse societies like Guyana and Suriname, independence may engender great feelings of uncertainty, mainly for minority groups, if power is distributed unequally and certain groups are excluded politically. Thus, the move towards independence is intertwined with a population's class and ethnic composition, with potentially significant consequences for emigration. Overall, if the public debate around independence is riddled with anxiety and high degrees of uncertainty, we should expect a rapid increase in emigration volumes; conversely, a highly desired and anticipated independence would not encourage large-scale emigration. Similarly, if border regimes are established without other major social changes in a relatively stable society, most people would not be motivated to emigrate. But border closure during unstable times could generate anxieties that lead larger segments of the population to pursue emigration before they lose their opportunity.

Understanding the historical juncture also entails assessing people's awareness of change. How much of the population knows about the border closure or upcoming independence? How far in advance do they know? Research shows that, because visas may be introduced in a subtle way, they do not consistently result pre-emptive migration (Czaika and de Haas 2017). Yet a major change, such as independence, would generate ample public debates and great uncertainties, and give people the opportunity to plan ahead. Therefore, we can conclude the advance knowledge people possess about a transition significantly affects their ability to emigrate.

\section{Sequence of change}

The modified schematic model (Figs. 7, 8 and 9) showed that the sequence of change matters (Abbott 2001). When we merge the observations from the three Guianas (Fig. 10) we observe that closing the border regime after independence leads to the rapid increase of migration volumes as a large proportion of the population is affected by independence ( $\left(t^{1}\right.$, Fig. 10) and it encourages sustained migration until people's movement is restricted by the closure of the borders ( $t^{2}$, Fig. 10). Conversely, closing a border regime before independence stunts migration opportunities in the short- to medium-term, until people are able to migrate to new destinations. However, if sizeable migrant communities have already formed at the destination (as with Surinamese in the Netherlands), and if the former colony has strong cultural and linguistic ties to the destination country, the border closure is likely to have a limited effect because migrant networks will facilitate family and other forms of migration. By accounting for typical sequences of events, we can analyse the interaction between these events and include other relevant factors operating at the time (Abbott 2001), such as the potential anxieties in anticipation of independence or of the removal of the right to migrate, ethnic tensions and cultural affinities with the former colonial state. Such an analytical framework facilitates the explanation of why similar political and policy changes might engender distinct changes in volumes, composition and direction of migration. 


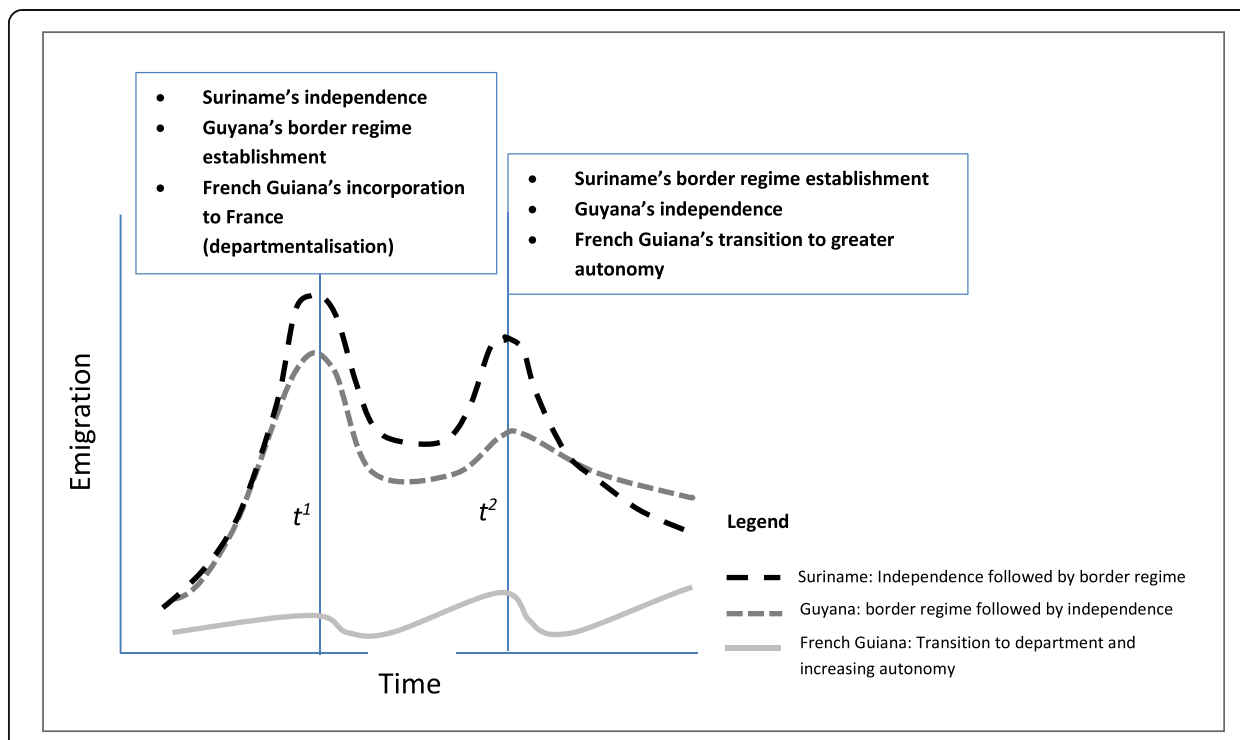

Source: Vezzoli 2015.

Fig. 10 Schematic representation of migration trends for Guyana, Suriname and French Guiana with respective moments of transition

\section{Time span}

The distinction between short- and long-term migration effects of independence and border regimes should not be underestimated. Guyana and Suriname illustrate how a new border regime and independence encourage immediate large emigration peaks, but then constrain migration. In the long-term, however, potential migrants identify other migration channels and destinations. This was noted for the Caribbean region as a whole, as in the long-term, closed borders with the former colonial state led to increasing emigration intensity (Flahaux and Vezzoli 2018). Thus, in the long term, border regimes do not decrease migration volumes, but they tend to diversify the modality of migration and destinations.

The case of French Guiana informs that, in the short-term, the transition to nonsovereignty leaves emigration patterns unchanged. In fact, by reducing uncertainties and enabling stability, non-sovereignty may decrease emigration. Over the long-term, the continuous open border leads to low and stable migration, because migration is influenced by political and socio-economic factors and various policy interventions. The same pattern was observed for the other non-sovereign countries in the Caribbean region (Flahaux and Vezzoli 2018).

In all our cases, we see that state policies greatly influence emigration in the longterm. For example, the three Guianas have all faced high unemployment rates and lack of economic diversification, yet by providing aid, public employment opportunities and public benefits, France has acted as a 'stabiliser' and recurrently slowed down emigration from Guyane. In contrast, limited interventions by the Guyanese and Surinamese governments resulted in continued economic instability and significant emigration volumes. By adopting a long-horizon we also observe the relevance of the 'pacing of change': for example, Guyanese rapidly turned away from Britain as a result of a strong US intervention and Britain's retreat during the independence process, while for the Surinamese the Netherlands remained a strong focal point and only now young Surinamese entertain the idea of studying in the US. Interestingly, even in French Guiana, Quebec is emerging as a 
new destination for health workers. The influence of the former colonial state on emigration seems to decline over time, but the pacing of this change varies significantly. This trend reveals people's desire to experience new horizons and it alerts us that post-colonial ties, as many other factors, waver in importance over time: while their relevance may be waning now, they could resurge in importance at a later date (Abbott 2001).

\section{Conclusion}

This article examines how political transitions and changes in border regimes affect migration. Using a historical approach to decolonisation and border regime shifts in the three Guianas, this article presents the factors and dynamics that led to the peaks and valleys observed in their migration patterns. Then, it proposes a schematic conceptual model to examine the interaction between post-colonial political transition and border regime change and explain shifts in the volumes, nature and destination of migration. The findings reveal the naivety of those who argue for closed borders, or who suggest all former colonies experience post-colonial ties and the same migration effects without considering political and broader societal changes.

Applying the proposed schematic conceptual model to the three Guianas highlights the dynamics that lead closed borders to produce high emigration and open borders to encourage people to stay. An important insight emerging from the model is the relevance of three aspects of time, namely the historical juncture during which border regimes change, the sequencing of political transitions and border control shifts, and the short versus long term effects.

This study shows, first, that border closure and independence must be understood within a specific historical juncture that produced hope and grave anxieties in former colonies and colonial immigration fears in metropolitan states. Therefore, at times, populations in the former colonies sought to secure their futures through emigration.

Second, when independence and border regime closure occur at different times, the sequence of change greatly explains shifts in migration volumes, channels, new destinations, migration composition and the effects of post-colonial ties. Border closure before independence encourages a rapid diversification of migration channels and destinations, while independence before border closure tends to concentrate migration in the former colonial state, postponing the reliance on alternative migration channels and overall weakening the search for alternative destinations, even in the long-term. The latter sequence encourages strong migrant networks in the former colonial state, bolsters postcolonial ties and lowers the effectiveness of border closure.

Third, independence and border regime change have distinct short- and long-term migration effects (time span). In the short term we see relatively high but temporary peaks associated with border closure, but migration levels return to previous trends in the long term. Open borders lead to stable emigration with gradual growth and great stability. Thus, closed border regimes do not prevent migration, and yield important effects that lead to migration diversification. Moreover, over the long-term, we observe that change takes place following distinct pacing, so that enduring political, social, economic and cultural connections with the former colonial state would reinforce migration to that destination, while a rapid reorientation - as from Guyana's shift from Britain to the US - would swiftly redirect migration to a new destination. 
Finally, the findings show that metropolitan state and former colonial states' various policies affect migration in the long term. The former colonial state may allow conditions to deteriorate, thereby stimulating emigration despite closed borders. Or, as observed in French Guiana, the metropolitan state may regularly intervene to reinstate stability. The latter approach seems to keep migration levels steady despite the open border regime.

While this article focuses on the three Guianas and the Caribbean region, the same model and considerations can be applied to other cases, such as the Pacific islands and other countries that gained independence. Moreover, the concepts of historical juncture, sequence of change and time span can be applied to a wide variety of political, institutional and economic changes to better understand their influence on migration.

\section{Supplementary Information}

The online version contains supplementary material available at https://doi.org/10.1186/s40878-020-00213-1.

Additional file 1. Interviewees' main demographic and migration information (de Bruijne 2001).

\section{Acknowledgements}

The author thanks Hein de Haas, Kerilyn Schewel, Sonja Fransen, Katharina Natter, Dominique Jolivet, Prof Asmamaw Legass and Siebert Wielstra for their valuable comments on early drafts of this article. The author also thanks Kirin Kalia for her invaluable work in editing the paper and for the helpful comments of two anonymous reviewers.

\section{Author's contributions}

This article reflects original work by the author. The author read and approved the final manuscript.

\section{Funding}

The research leading to these results was part of the DEMIG (The Determinants of International Migration) project and received funding from the European Research Council under the European Community's Seventh Framework Programme (FP7/2007-2013) / ERC Grant Agreement 240940. The reconceptualization and revision of this article are supported by the MADE (Migration as Development) Consolidator Grant project, receiving funding from the European Research Council under the European Community's Horizon 2020 Programme (H2020/2015-2020)/ERC Grant Agreement 648496.

\section{Availability of data and materials}

The migration datasets used and analysed during the current study are available directly from the sources cited in the figures, e.g. World Bank, DEMIG databases. The qualitative data is available from the corresponding author on reasonable request.

\section{Competing interests}

The author declares that she does not have any competing interests.

Received: 3 June 2020 Accepted: 6 November 2020

Published online: 19 March 2021

\section{References}

Abbott, A. (2001). Time matters: on theory and method. Chicago: The University of Chicago Press.

Bosma, U., Lucassen, J. M. W. G., \& Oostindie, G. J. (2012). Introduction. Postcolonial migrations and identity politics. Towards a comparative perspective. In U. Bosma, J. Lucassen, \& G. Oostindie (Eds.), Postcolonial Migrants and Identity Politics (pp. 122). Amsterdam: Koninklijk Instituut voor Taal-, Land- en Volkenkunde(KITLV), Internationaal Instituut voor Sociale Geschiedenis (IISG).

Castles, S. (2010). Understanding global migration: A social transformation perspective. Journal of Ethnic and Migration Studies, 36(10), 1565-1586.

Chin, H. E., \& Buddingh', H. (1987). Surinam: politics, economics and society. London and New York: France Pinter.

Clegg, P. (2005). The UK Caribbean overseas territories: extended statehood and the process of policy convergence. In L. de Jong, \& D. Kruijt (Eds.), Extended statehood in the Caribbean: paradoxes of quasi colonialism, local autonomy and extended statehood in the USA, French, Dutch and British Caribbean (pp. 125-156). Amsterdam: Rozenberg Publishers.

Czaika, M., \& de Haas, H. (2013). The effectiveness of immigration policies. Population and Development Review, 39(3), 487-508. Czaika, M., \& de Haas, H. (2017). The effect of visas on migration processes. International Migration Review, 51(4), $893-926$.

de Bruijne, A. (2001). A city and a nation: demographic trends and socioeconomic development in urbanising suriname. In R. Hoefte, \& P. Meel (Eds.), Twentieth-century suriname: continuities and discontinuities in a New World Society (pp. 23-47). Kingston: lan Randle Publishers.

de Haas, H. (2011). The determinants of international migration: conceptualizing policy, origin and destination effects. In IMI working papers No. 32. Oxford: International Migration Institute. 
de Haas, H., Czaika, M., Flahaux, M. L., Mahendra, E., Natter, K., Vezzoli, S., \& Villares-Varela, M. (2019b). International migration: trends, determinants, and policy effects. Population and Development Review, 45(4), 885-922.

de Haas, H., Natter, K., \& Vezzoli, S. (2018). Growing restrictiveness or changing selection? The nature and evolution of 759 migration policies. International Migration Review, 52(2), 324-367.

de Haas, H., Vezzoli, S., \& Villares-Varela, M. (2019a). Opening the floodgates? European migration under restrictive and liberal border regimes (In IMI working paper series). Amsterdam: IMI.

DEMIG (2015). DEMIG TOTAL, version 1.5. Oxford: International Migration Institute, University of Oxford; DEMIG (2015) DEMIG C2C, version 1.2, Full Edition. Oxford: International Migration Institute, University of Oxford.

Dew, E. (1978). The difficult flowering of Surinam: Ethnicity and politics in a plural society. The Hague: Martinus Nijhoff.

Engbersen, G., Okólski, M., Black, R., \& Pantîru, C. (2010). Working out a way from East to West: EU enlargement and labour migration from Central and Eastern Europe. In G. Engbersen, R. Black, M. Okólski, \& C. Pantîru (Eds.), A continent moving West? EU enlargement and labour migration from Central and Eastern Europe (pp. 7-22). Amsterdam: Amsterdam University Press.

Executive Council of British Guiana (1961). Minutes of a Meeting of the Executive Council of British Guiana held on 18 November 1961. Georgetown: Executive Council of British Guiana.

Flahaux, M.-L., \& Vezzoli, S. (2018). Examining the role of border closure and post-colonial ties in Caribbean migration. Migration Studies, 6(2), 165-186.

Freeman, G. P. (1987). Caribbean migration to Britain and France: from assimilation to selection. In B. B. Levine (Ed.), The Caribbean Exodus. Westport and London: Praeger.

Gaztambide-Géigel, A. (2004). The invention of the Caribbean in the 20th century. Social and Economic Studies, 53(3), 12757,77 .

Gowricharn, R. (2004). Moral capital in Surinamese transnationalism. Ethnic and Racial Studies, 27(4), 607-621.

Grosfoguel, R. (1996). Colonial Caribbean migrations to the metropoles in comparative perspective. Journal of Social Sciences, $3(1+2), 20-39$

Guengant, J.P. (1993). Migrations : moins de départs, plus d'arrivées. Antiane, 22, 30-32.

Kureková, L. (2011). From job search to skill search: political economy of labor migration in central and Eastern Europe. In Department of international relations and European studies. Budapest: Central European University.

Laing, E. A. (1979). Independence and islands: the decolonization of the British Caribbean. The New York University Journal of International Law and Politics, 12, 281.

Marie, C. V., \& Rallu, J. L. (2004). Migrations croisées entre DOM et Métropole: l'emploi comme moteur de la migration. Espace Populations Sociétés. Space Populations Societies, (2004/2), 237-252.

Marie, C.-V., Temporal, F., Breton, D., \& Chanteur, B. (2012). Migrations, Famille et Vieillissement: Défis et enjeux pour la Guyane. In Antianéchos. Paris: INSEE Antille-Guyane; INED.

Marshall, D. (1987). A history of west Indian migrations: overseas opportunities and "safety-valve" policies. In B. B. Levine (Ed.), The Caribbean exodus. Westport: Praeger Publishers.

McElroy, J., \& Sanborn, K. (2005). The propensity for dependence in small Caribbean and Pacific islands. Bank of Valletta Review, 31(1), 16.

Menke, J. (1998). Restructuring urban employment and poverty: the case of Suriname. Paramaribo: SWI Press.

Mitchell, S. A., \& McElroy, J. L. (2011). Emigrant and immigrant small island profiles. Bank of Valletta Review, 43(Spring), 1-11.

Moore, B. (2001). Decolonization by default: Suriname and the Dutch retreat from empire. In K. Fedorowich, \& M. Thomas (Eds.), International diplomacy and colonial retreat (pp. 228-250). London: Frank Cass.

Okólski, M., \& Salt, J. (2014). Polish emigration to the UK after 2004; why did so many come? Central and Eastern European Migration Review, 3(2), 11-37.

Osburg, M. (2020). State expansion, mobility and the aspiration to stay in Western French Guiana (In IMI working paper series, pp. 1-31). Amsterdam: International Migration Institute.

Peach, C. (1968). West Indian migration to Britain: a social geography. London: Oxford University Press.

Sanger, C. (1966). The economics. London: The Guardian.

Temporal, F., Marie, C.-V., \& Bernard, S. (2011). Insertion professionelle des jeunes ultramarins: DOM ou métropole? PopulationF, 66(3-4), 555-600.

United Nations, Department of Economic and Social Affairs, Population Division (2013). World Population Prospects: The 2012 Revision, DVD Edition, Estimates 1950-2010.

van Amersfoort, H. (2011). How the Dutch Government stimulated the unwanted immigration from Suriname (In IMI working papers, no. 47). Oxford: International Migration Institute.

Vezzoli, S. (2015). Borders, independence and post-colonial ties: the role of the state in Caribbean migration. Maastricht: Maastricht Graduate School of Governance.

Wallace, C. (2002). Opening and closing borders: migration and mobility in East-Central Europe. Journal of Ethnic and Migration Studies, 28(4), 603-625.

\section{Publisher's Note}

Springer Nature remains neutral with regard to jurisdictional claims in published maps and institutional affiliations. 